\title{
THE CHARM OF DETAIL - LACES AND POINTS IN MEDIEVAL AND MODERN GARMENTS. AN EXAMPLE OF ARCHAEOLOGICAL FINDS FROM ELBLĄG
}

\begin{abstract}
A good fit of clothing to the body mainly depended on the perfect cut. Another way to fit clothes to the body shape was to use lacing. In the Middle Ages, women's gowns could be fitted with laced slits at the sides or in front of the dress. In men's medieval attire, lacing mainly concerned the fastening of doublets and it was always placed at the front. Strings had one more special task - they supported a pair of hose tied to the doublet. In the course of time, the laces became more visible, gradually gaining a decorative function. An interesting collection of laces from archaeological excavations is stored in the Museum of Archaeology and History in Elbląg. The earliest lace is dated back to the $13^{\text {th }}$ century, and another medieval find in this collection is a metal lace chape. Other artefacts are silk laces dated to the $16^{\text {th }}, 17^{\text {th }}$ and $17-18^{\text {th }}$ centuries. The Elbląg collection documents the development of this part of clothing. It certainly constitutes an important part of a relatively small assemblage of surviving European fashion accessories of this type.
\end{abstract}

Keywords: Elbląg (former Elbing), Middle Ages, clothing, laces, lace chapes, points

Received: 10.04.2020 Revised: 13.05.2020 Accepted: 09.06.2020

Citation: Rybarczyk A. 2020. The Charm of Detail - Laces and Points in Medieval and Modern Garments. An Example of Archaeological Finds from Elblag. "Fasciculi Archaeologiae Historicae" 33, 201-209, DOI 10.23858/FAH33.2020.014

Nowadays, there are many inventions and improvements that facilitate the production of clothes and improve the comfort of their use. Most clothes are products that easily adapt to the body and the use of knitted fabrics is extremely popular. Stretch fibres are also applied, which can add flexibility even to quite stiff woven fabrics. Such accessories as zippers or press studs are in common use which makes modern clothes not only comfortable and well-fitted, but also enables them to be put on quickly and easily. It is worth realising that this situation has only been the case for a relatively short time and for most of their history people were not able to enjoy all these advantages of clothing at the same time. What was the easiest to create and the most comfortable to wear was loose and rather baggy clothing, such as a tunic. It essentially took the same form in versions for both sexes and mainly differed in length.

* Institute of Archaeology and Ethnology, Polish Academy of Sciences, Łódź; (D) https://orcid.org/0000-0003-2210-1585; annamaria. rybarczyk@wp.pl
A final departure from this beaten track took place in the mid- $14^{\text {th }}$ century, when clothing which strongly emphasised the body shape became popular and at the same time, the length of men's garments became significantly shortened. Changes that took place during this period were of fundamental importance for the direction of the evolution of European costume in the following centuries. Furthermore, they also gave impetus to the development of the tailor's art.

A good fit of clothing to the body was difficult to achieve because it mainly depended on the perfect cut. Another way to fit clothes to the body shape was to use lacing. This easy method was already known - the earliest written and pictorial sources confirming the use of laces for tight fitting garments come from the $12^{\text {th }}$ century. ${ }^{1}$ Lacing was a very functional solution allowing the wearing of one robe as long as possible even if one's body dimensions changed. This was of special significance for

${ }^{1}$ Frieder Waugh 1999, 3-16. 


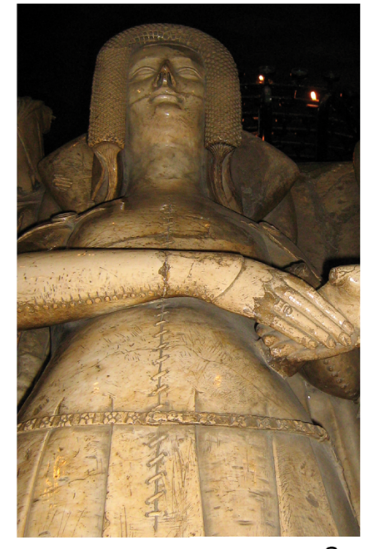

a
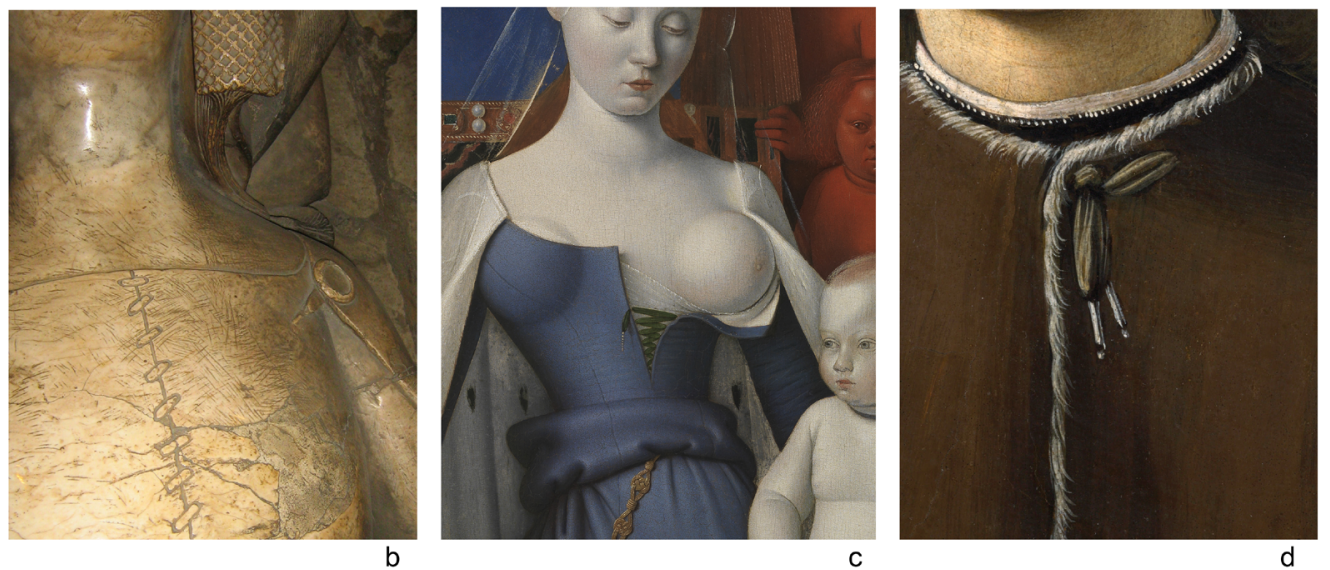

Fig. 1. a, b - effigy of Katherine Mortimer, St. Mary's Church, Warwick. Photo A. Rybarczyk, c - Virgin and Child Surrounded by Angels, right wing of the Melun diptych, Jean Fouquet, 1452, Royal Museum of Fine Arts, Antwerp. Close-up. d - Portrait of Young Man, Sandro Botticelli, 1483, National Gallery, London. Close-up.

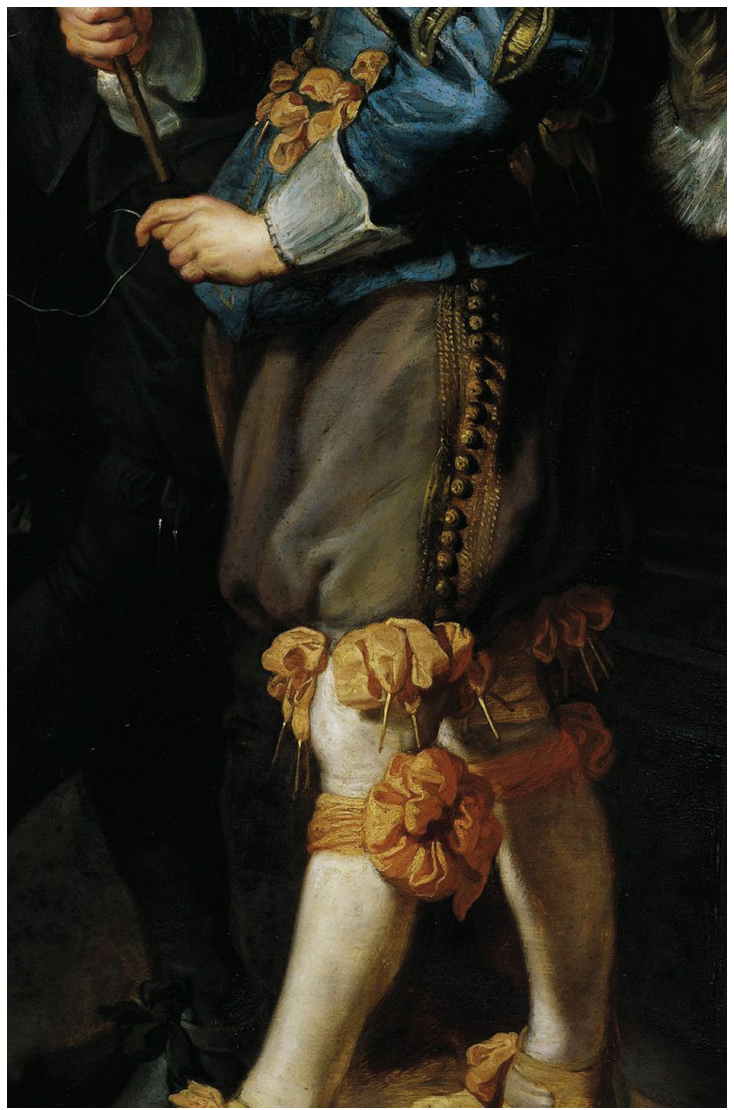

Fig. 2. Portrait of Albert and Nicolaas Rubens, Peter Paul Rubens, 1626-1627, Liechtenstein Museum, Vienna. Close-up.

pregnant women. In the Middle Ages, women's dresses could be fitted with laced slits at the sides or in front of the dress. On the basis of surviving iconographic sources, it seems that lacing was mainly used in kirtles worn as working dress. In formal outer gowns noticeable lacing appeared at the end of the $14^{\text {th }}$ century. Depictions of this type of dress with fastening running in the front can be found in European iconography of this period. A good example is offered by illuminations from the Willehalm (1387-1395), which was a manuscript commissioned by
King Wenceslaus IV of Bohemia. ${ }^{2}$ Another example is the effigy of Katherine Mortimer, wife of Earl Thomas Beauchamp, located in St. Mary's Church in Warwick (Fig. 1:a-b). In later periods, laces were increasingly observable. During the Renaissance, they even became a decorative element of the outfit.

In men's medieval attire, lacing mainly concerned the fastening of doublets and related forms of clothing and was always placed on the front of the garment. In men's clothing, strings had one more special task - they tied the hose to the doublet. Initially, until the mid- $14^{\text {th }}$ century men wore short, separate hose, which were fastened to the front of the braies or to a special girdle. In Polish written sources from the Late Middle Ages such a belt was referred to as a pas gacny or gac$n i k$, and the Latin term lumbae was also in use. ${ }^{3}$ A depiction of this kind of girdle can be seen on the bronze statue of Amor Atys made by Donatello in the 1430s. ${ }^{4}$ Hose were tied to the belt only in one place and thus this solution did not require the use of many strings.

The situation changed with fashion transformations which were initiated from the mid- $14^{\text {th }}$ century. During this period, major changes took place especially in men's clothing; upper body garments were significantly shortened, thus uncovering a greater part of the legs. Shortening men's dress resulted in a need to lengthen the hose and attach them in such a way that the thighs (and also the buttocks, as clothes became shorter and shorter in the course of time) were covered; otherwise underwear or even the naked body could be exposed. This new style required tying the hose in more than one place. In order to achieve this, instead of being attached

\footnotetext{
${ }^{2}$ Krasa 1971, 122, 125, 266.

${ }^{3}$ Turska 1987, 79.

${ }^{4}$ The sculpture is stored in the Museo Nazionale del Bargello
} in Florence. 

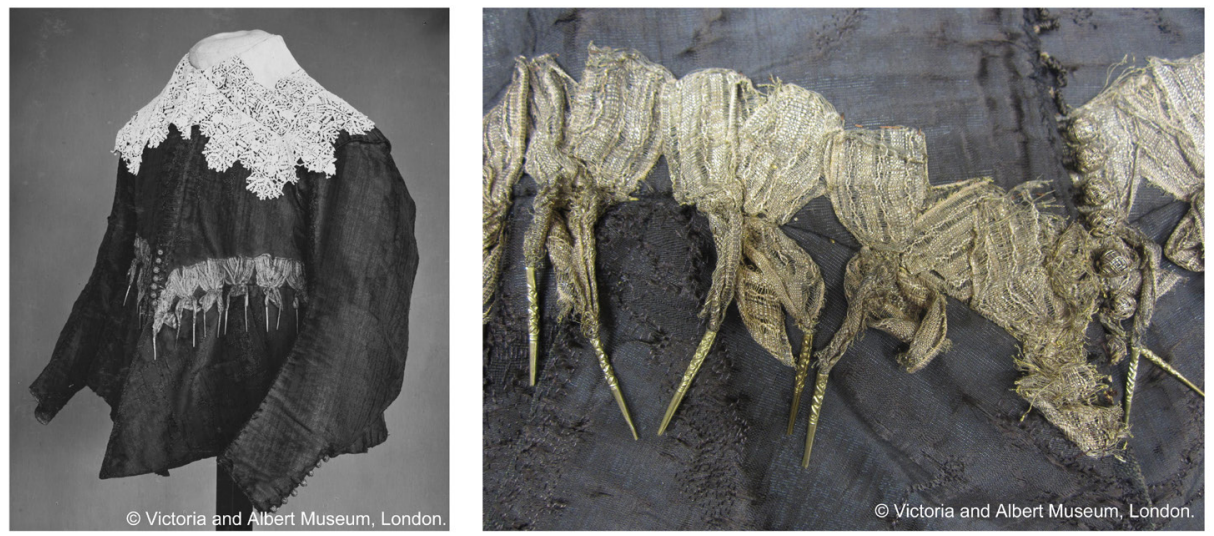

Fig. 3. Doublet, c. 1630-1635, inv. no.: 185-1900, Victoria and Albert Museum, London.

to the girdle the hose were now tied to a new fashionable piece of clothing - a doublet. The appearance of this garment is associated with a significant increase in the demand for short laces with fittings at both ends, known as points. Along the bottom edge of doublet there were evenly distributed pairs of holes, through which the points were threaded. A corresponding number of holes were also located in the upper edge of the hose. At least four strings were used to attach the hose to the doublet (there could have been more of them, and their usual number was nine ${ }^{5}$ ), and several others were needed to tie up the front of the garment. According to a record from the English Great Wardrobe Account from 1343-1344, twenty four lace chapes were used for a single aketon. ${ }^{6}$ The lacing of the doublet is also mentioned in the accounts of the royal court of Queen Jadwiga and King Władysław Jagiełło from 1394. Thanks to these notes, we learn that a tailor Henricus received 6 Groschen for strings to the king's satin jopula: item pro snury ad ioppulas Regis athlasz griseo per Henricum sartorem VI $\mathrm{gr}^{7}$ Unfortunately, this mention does not specify how many strings were obtained for this money.

The height at which holes were punched in the doublet in order to tie the hose changed over time. In $14^{\text {th }}$ century doublets which were long enough to cover the hips, the holes were placed low, near the bottom edge. In later years, the holes were placed higher and finally they were situated at waist height. This was the result of an elongation of the hose and a gradual transformation of their form, up to that resembling present-day trousers.

Just like laces in a woman's outfit, the points became more noticeable in the course of time and they were gradually gaining a decorative function. In Italian fashion of the $2^{\text {nd }}$ half of the $15^{\text {th }}$ century, short laces were attached to sleeves to hang loosely, thus fulfilling solely an ornamental purpose. It was probably meant

\footnotetext{
${ }^{5}$ Egan and Hayward 2012, 422.

${ }^{6}$ Newton 1980, 136.

${ }^{7}$ Rachunki dworu..., 185.
}

to imitate military fashion. In arming doublets points were attached to the sleeve and they were used to fix upper arm guards. ${ }^{8}$

In the course of time, apart from plain strings and braids, wide and very decorative ribbons were also used as laces. Their purpose was not only to tie breeches to the doublet, but also to attach stockings to breeches, as it is shown in the Portrait of Albert and Nicolaas Rubens painted by Peter Paul Rubens c. 1626-1627 (Fig. 2). Remains of silk stockings preserved together with attached points were discovered in Szczecin, in the burial of Duke Ulrich of Pomerania, who died in $1622 .{ }^{9}$ In the men's doublets of the end of the $16^{\text {th }}$ century and the $1^{\text {st }}$ half of the $17^{\text {th }}$ century, numerous decorative ribbons were attached at the waistline, where the breeches were usually fastened. An example of such decorations can be seen in the doublets stored in the collection of the Victoria and Albert Museum in London and the Metropolitan Museum of Art in New York (Figs. 3 and 4).

Interestingly, laces were not only used for lacing dresses and doublets or for attaching hose. As it can be seen in the artefact stored in the Victoria and Albert Museum (Fig. 5), lacing was also applied to adjust woven fabric stockings so that they fit snugly to the leg. Woven textile stockings or hose were not as flexible as their knitted counterparts. The artefact in question comes from the beginning of the $17^{\text {th }}$ century, that is, from the period when knitted stockings already prevailed. It can be assumed, however, that such a solution was also used earlier in the Late Middle Ages, when knitted leg covers had not yet gone into widespread use, and when fashion was already creating demand for very narrow hose that could emphasise the shape of the leg.

So far, I have tried to discuss briefly the function of laces in medieval and modern-period clothing. Right now, I should mention what form they could actually take. The simplest variant that could be used is

\footnotetext{
${ }^{8}$ Capwell 2002, 183-184.

${ }^{9}$ Januszkiewicz 1995, 102-107.
} 

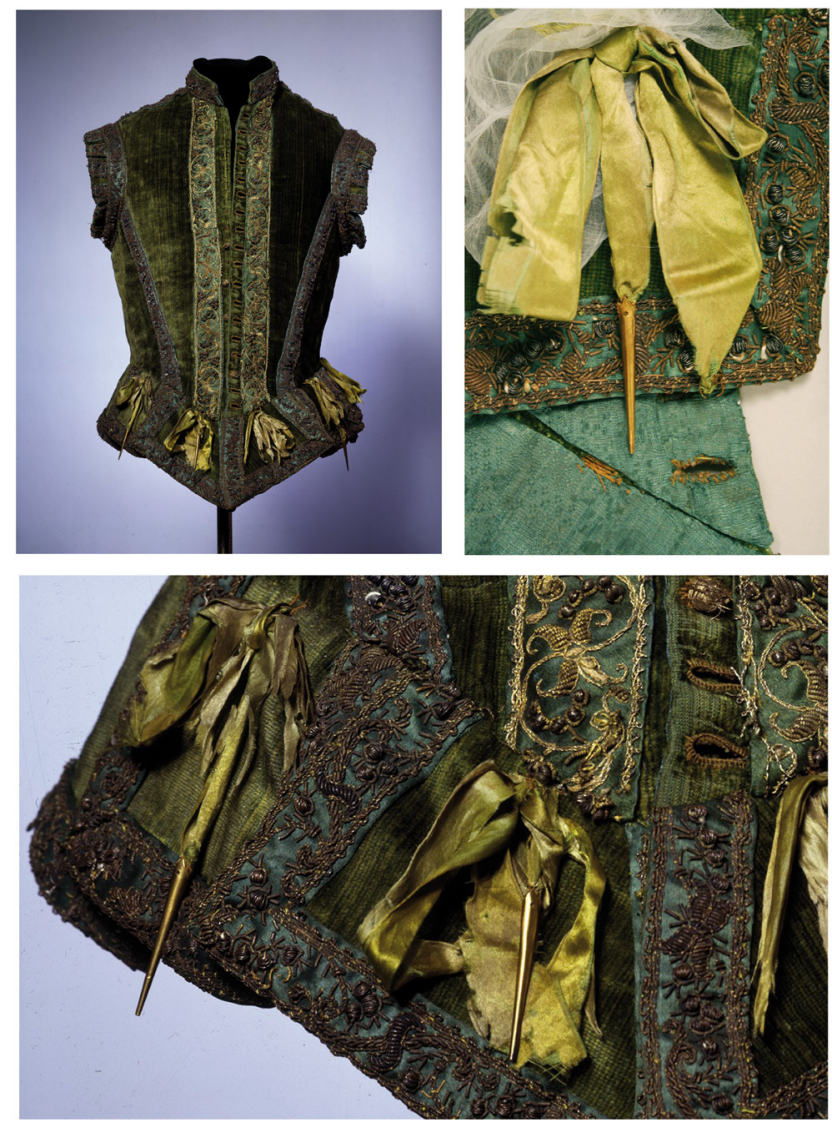

Fig. 4. Doublet, c. 1580, accession no.: 1978.128, Metropolitan Museum of Art, New York.
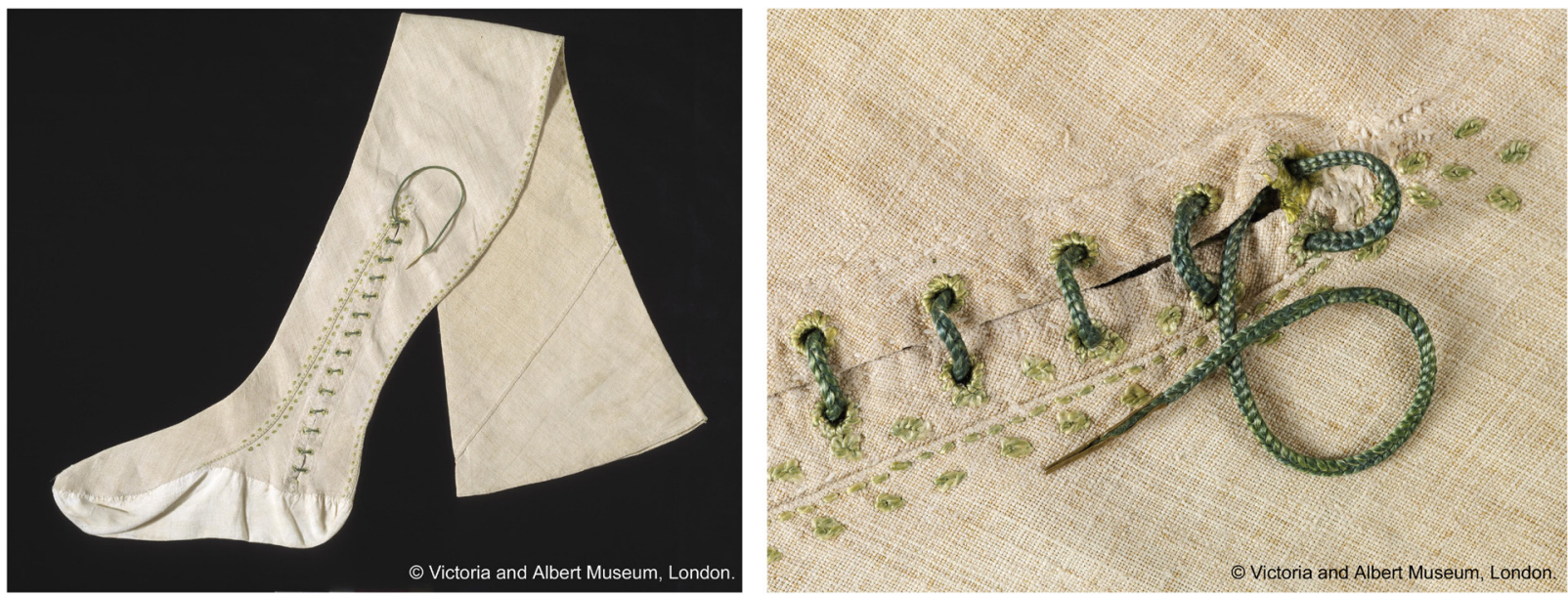

Fig. 5. Pair of stockings, c. 1590-1615, inv. no.: T.126\&A-1938, Victoria and Albert Museum, London.

just a cord or leather strap. However, what changed a piece of string or ribbon into a proper lace was the fitting. A metal chape not only made it easier to thread the lace through the holes or special metal rings sewn on the fabric, but also protected the end of the string from damage. Lace chapes were made of thin metal sheet that was rolled to form a cylindrical tapering tube. With regard to their functions and appearance, such fittings resembled needles. This was reflected in their French (aguilette, aiguilette) and English (aglet, aiglet) names derived from the Latin word acus. ${ }^{10}$ Another contemporary English term describing both short laces as well as their chapes is points. ${ }^{11}$ Medieval lace tags are known only from archaeological excavations. However, artefacts from later periods survived with costumes kept in museum collections. Archaeological finds of lace chapes were typologically divided

\footnotetext{
${ }^{10}$ Picken 1957, 6.

${ }^{11}$ Egan and Pritchard 2002, 281.
} 


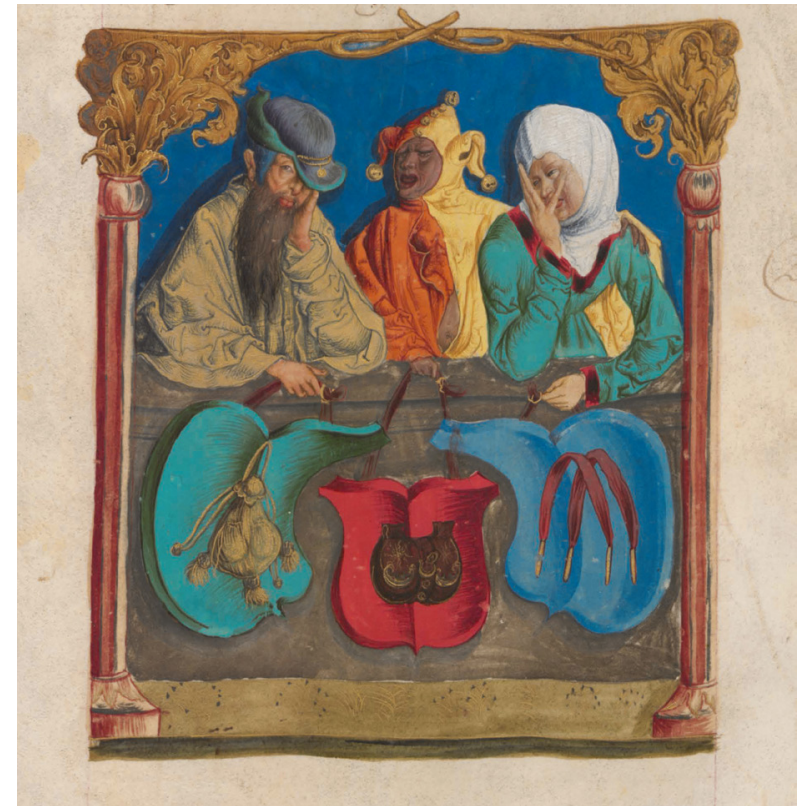

Fig. 6. The coat of arms of the purse-makers guild, Balthasar Behem Codex, c. 1505, Jagiellonian Library, BJ Rkp. 16.

by S. Krabath, who distinguished seven types of these fittings. ${ }^{12}$

Lace chapes were small artefacts which were often hidden under layers of clothing. Thus, they were not easy to notice. They hardly ever appeared in iconography before the $15^{\text {th }}$ century, when the artists commenced to pay more attention to details in their works. The most famous painting which depicts a lace ending a chape is the image of the Virgin and Child Surrounded by Angels by Jean Fouquet (Fig. 1:c). Laces are also shown on numerous other works of art of this time, such as the Portrait of Young Man by Sandro Botticelli (Fig. 1:d), or the Portrait of Jacques of Savoy by Hans Memling.

By means of investigating various iconographic representations, it can be seen how the laces were tied. Longer laces with a fitting at one end were used for lacing women's dresses and less often for men's doublets. Clothes were laced differently from present-day shoes. Only one end of the lace went through the holes, while the other was attached at the first eyelet. Some ways of such lacing in the $15^{\text {th }}$ century are shown in Figure 1:a-c. Another method of tying that was typical for men's attire was the use of short strings passing through two or four holes and then tied with a half bow (Fig. 1:d). The same way of lacing was used for tying the hose to the doublet.

An interesting German iconographic source related to the discussed element of clothing is the Nuremberg guild book known as the Hausbücher der Nürnberger Zwölfbrüderstiftungen. It depicts representatives of various crafts at work. Among many other craftsmen there

\footnotetext{
${ }^{12}$ Krabath 2001, 228.
}

are also professionals involved in fitting laces. The earliest depiction shows Dyetz Nestler who died in 1423. The next ones present five other lace makers who were active in the $16^{\text {th }}$ and $17^{\text {th }}$ century. These illustrations provide some pieces of information about the tools needed to make laces, as well as the materials that were used. On the basis of animal hides hanging in workshops, it can be supposed that the laces shown in the guild book are made of leather. ${ }^{13}$ The use of leather as a raw material to make laces is also confirmed by another iconographic source, this time coming from Poland. It is the illumination from the Balthasar Behem Codex (1505), depicting the coat of arms of the purse-makers guild. Apart from other products such as a pouch and a purse, a pair of red laces can also be seen there (Fig. 6). Leather laces with metal chapes were discovered during excavations at Lengberg Castle in Austria and these finds date back to the $15^{\text {th }}$ century. ${ }^{14}$ Traces of leather were also found in a few medieval lace chapes discovered in London. ${ }^{15}$

A very interesting collection of laces is stored in the Museum of Archaeology and History in Elbląg. These artefacts come from excavations conducted in the Elbląg's Old Town since the 1980s. The earliest and therefore the most interesting item in the discussed collection is a silk lace with remains of the fitting. This find is dated to the $13^{\text {th }}$ century ${ }^{16}$ (inv. no. EMXXII/32/12.787) (Fig. 7). This artefact has already been published by J. Maik. ${ }^{17}$ The band is $0.9 \mathrm{~cm}$ wide and was most likely braided open-ended with 20 threads. Its preserved length with the remains of the chape is $23.5 \mathrm{~cm}$. The fitting's surviving length is $1.6 \mathrm{~cm}$. The remains of the chape are, unfortunately, heavily corroded. Reddish colour of the metal remains and its reaction to magnet indicates that is iron. To the best of my knowledge it is the earliest find of this type, i.e. a lace with an attached fitting. The second find comes from the very end of the Middle Ages. A well preserved lace consisting of a silk string was found in a late $15^{\text {th }}$ century deposit in Fast Castle in Scotland. ${ }^{18}$ The chapes themselves, however, often occur in archaeological material, just to mention examples from England, ${ }^{19}$ Scotland, ${ }^{20}$ Germany, ${ }^{21}$ Austria ${ }^{22}$ and Bohemia. ${ }^{23}$

\footnotetext{
${ }^{13}$ Die Hausbücher der Nürnberger Zwölfbrüderstifungen

${ }^{14}$ Nutz 2014, 128

${ }^{15}$ Egan and Pritchard 2002, 282.

${ }^{16}$ The dating of the deposits from which the discussed arte-
} facts come from was carried out by $\mathrm{PhD}$ Mirosław Marcinkowski, whom I would like to thank for his help.

${ }^{17}$ Maik 2004, 510-511. In this publication the artefact was dated to the $14^{\text {th }}$ century.

${ }^{18}$ Ryder and Gabra-Sanders 1992, 5, 7-9.

${ }^{19}$ Egan and Pritchard 2002, 281-290.

${ }^{20}$ Caldwell and O’Neil 1991, 338, 340, Fig. 3.17.

${ }^{21}$ Krabath 2001, 521-524.

22 Nutz 2014, 128.

${ }^{23}$ Cymbalak and Svatošová 2015, 9. 


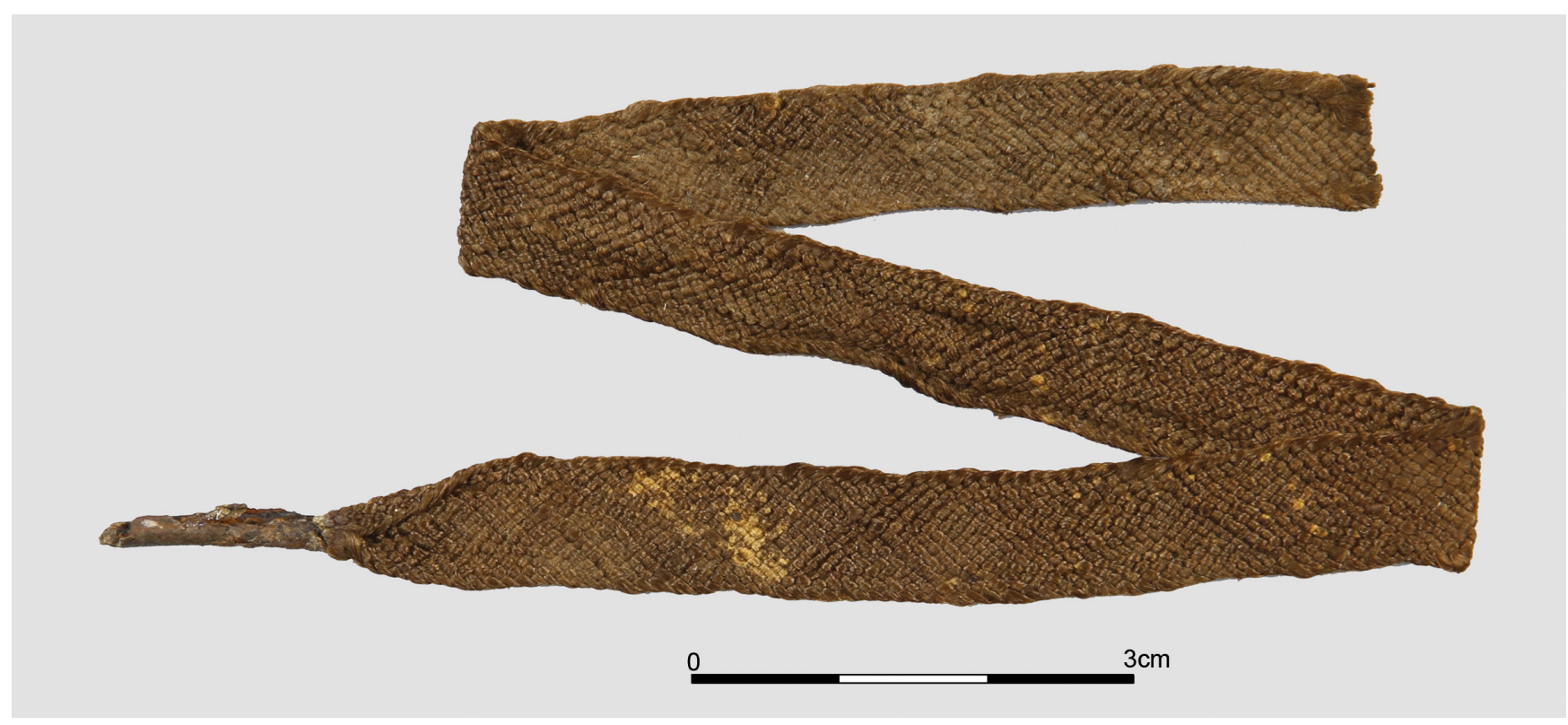

Fig. 7. Silk lace, $13^{\text {th }}$ century, inv. no. EMXXII/32/12.787, Museum of Archaeology and History in Elbląg. Photo A. Rybarczyk.

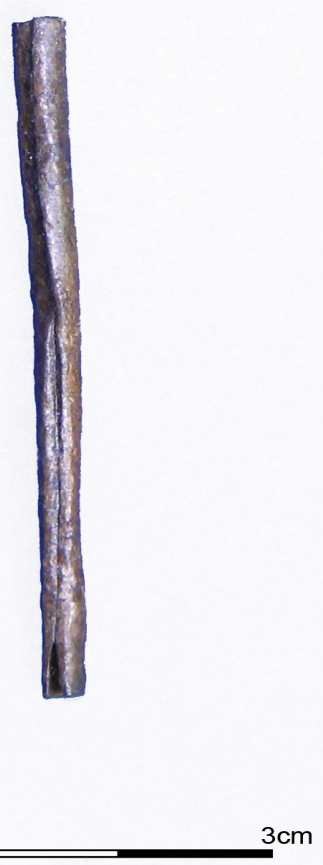

Fig. 8. Lace chape, $14^{\text {th }}$ century, inv. no. EMII/435, Museum of Archaeology and History in Elbląg. Photo A. Rybarczyk.

Another medieval artefact is a lace chape (inv. no. EMII/435) which is dated to the turn of the $13^{\text {th }}$ and $14^{\text {th }}$ century (Fig. 8). The lace end was made of thin copper alloy sheet. The chape is quite long, measuring almost $5 \mathrm{~cm}$. Its diameter at the widest point is about $0.4 \mathrm{~cm}$. The fitting slightly narrows towards the end and has no trace of a rivet, so it must have been simply clamped on the ribbon or thong.

The next lace discovered in Elbląg (Fig. 9) dates back to the $16^{\text {th }}$ century (inv. no. EMXXXI/22/755). It was made of silk string braided of three loops using the fingerlooping method. The present-day colour of the artefact is light yellowish, which suggests that the threads were most likely not dyed. The string is $0.35 \mathrm{~cm}$ thick and it ends with a $3.1 \mathrm{~cm}$ long metal chape. The tag has a tapered shape - its diameter at the widest point is $0.3 \mathrm{~cm}$, while the minimum width is $0.2 \mathrm{~cm}$. The wider end of the chape is slightly bent inwards. The fitting was made of copper alloy. This chape, just like the one discussed above, has no rivet and was only firmly tightened on the string. The total length of the lace is $17 \mathrm{~cm}$. A similar but completely preserved artefact which dates back to the $16^{\text {th }}$ century is kept in the collection of the Museum of London. Unlike the Elblagg example, the London fitting is provided with a rivet.

Another artefact (Fig. 10) comes from the $17^{\text {th }}$ century (inv. no. EMXXX/34/5545). Two silk ribbons, currently yellow, with fittings at both ends are tied together with a knot. Their total length including the fittings is approximately at least $40 \mathrm{~cm}$. The ribbons are $2.1 \mathrm{~cm}$ wide. Their selvedge is made in tabby weave, while the rest is in extended tabby. The warp density is 54 threads per $\mathrm{cm}$ and the weft is 20 threads per $\mathrm{cm}$. The chapes are made of iron. Likewise the other Elbląg lace chapes, these fittings have no rivets.

The last artefact (Fig. 11) from the collection in question is dated to the $17^{\text {th }}-18^{\text {th }}$ century (inv. no. EMXXXIII/27/2657). The ribbon and the fitting measure $27 \mathrm{~cm}$ altogether, while the ribbon width is $2.9 \mathrm{~cm}$. Ribbon selvedge is made in extended tabby weave, the rest is tabby. The warp density is 33 threads per centimetre, and the weft is 20 threads per $\mathrm{cm}$. The current colour of the ribbon is dark brown, thus it can be assumed that it was dyed. The chape attached to the band is $1.6 \mathrm{~cm}$ long and 


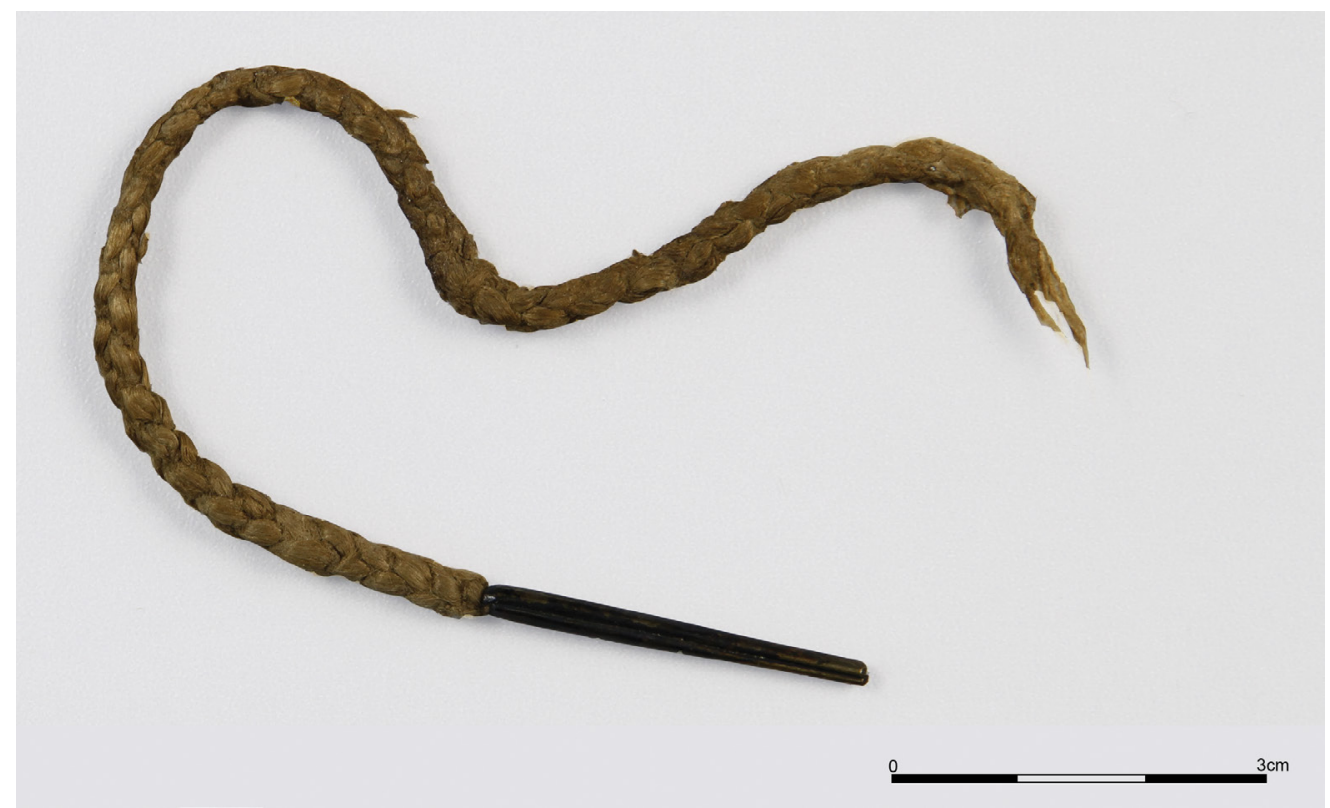

Fig. 9. Silk lace, $16^{\text {th }}$ century, inv. no. EMXXXI/22/755, Museum of Archaeology and History in Elbląg. Photo A. Rybarczyk.

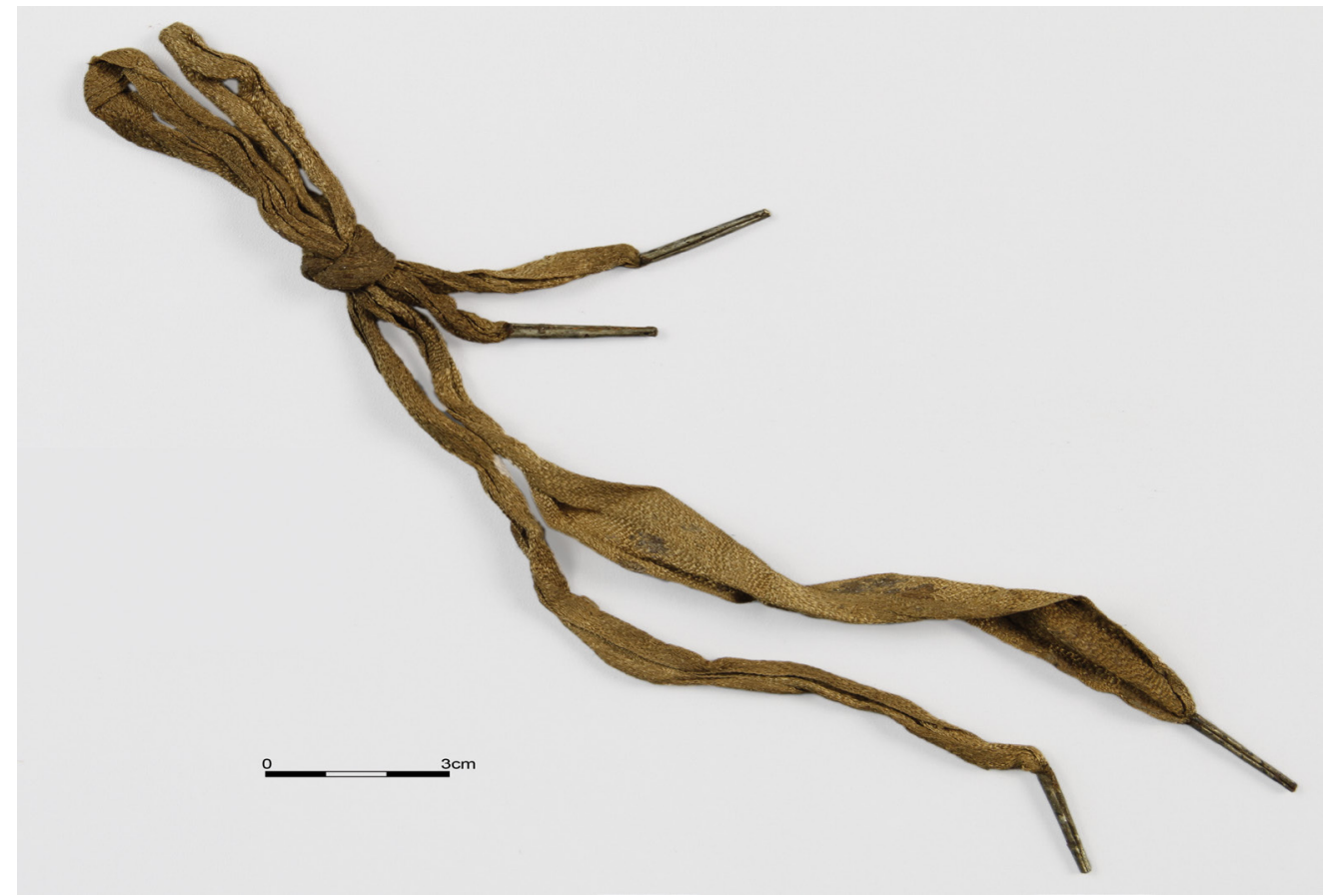

Fig.10. Pair of silk laces, $17^{\text {th }}$ century, inv. no. EMXXX/34/5545, Museum of Archaeology and History in Elbląg. Photo A. Rybarczyk.

is made of iron. Like the other aforementioned tags, this one was also only tightened on the ribbon, without using a rivet. Typologically, this and all other Elbląg chapes correspond to Type 1 according to Krabath's typology (cylindrical and slightly cone shaped). ${ }^{24}$

\section{Conclusions}

The discussed assemblage of Elbląg artefacts, although limited in number, is undoubtedly worthy of our

\footnotetext{
${ }^{24}$ Krabath 2001, 228.
}

attention. It contains laces from different periods and documents the development of this detail of clothing. It certainly constitutes an important part of a relatively small assemblage of surviving European fashion accessories of this type. While the discoveries of the fittings themselves or of various types of strings and ribbons are not unique, examples of fully preserved laces consisting of both textile and metal parts are relatively rare. Most of archaeological finds of haberdashery cannot be undoubtedly determined with regard to their original use. The case of the ribbons ended with tags is different, which makes these finds unique. 


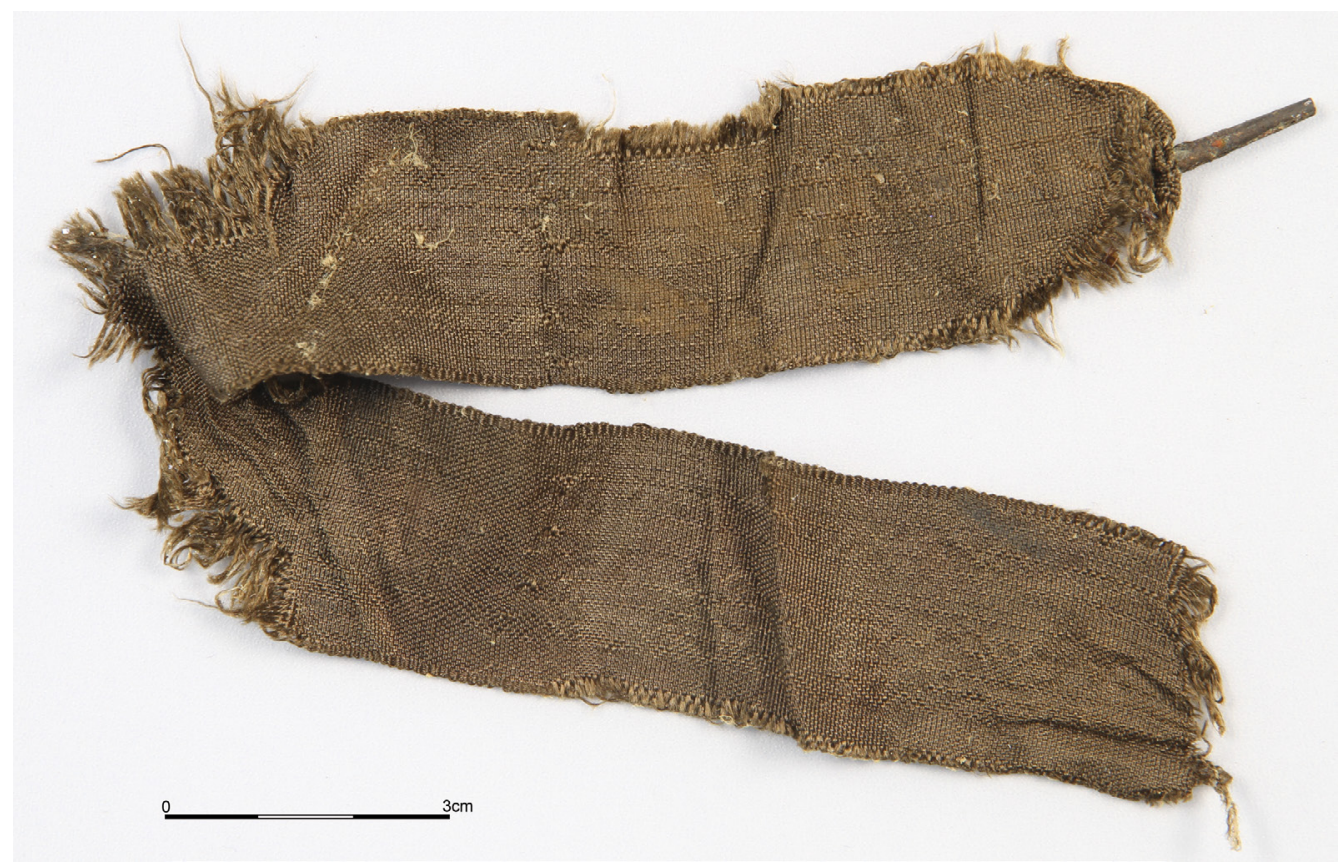

Fig.11. Silk lace, $17^{\text {th }}-18^{\text {th }}$ century, inv. no. EMXXXIII/27/2657, Museum of Archaeology and History in Elbląg. Photo A. Rybarczyk.

\section{Sources}

Hausbücher der Nürnberger Zwölfbrüderstiftungen - Hausbuch der Mendelschen Zwölfbrüderstiftung, Band 1, Nürnberg. Mendelsche Zwölfbrüderstiftung Papier, Nürnberg, 1426-1549. Germanisches Nationalmuseum Nürnberg Amb. $317.2^{\circ} \mathrm{https}: / /$ hausbuecher.nuernberg.de. Available on-line 09.04.2020.

Rachunki dworu - Rachunki dworu króla Władystawa Jagietty i królowej Jadwigi z lat 1388 do 1420, ed. F. Piekosiński. Kraków 1896.

\section{Bibliography}

Caldwell D. H., O’Neil M. 1991. Tantallon Castle, East Lothian: a Catalogue of the Finds. "Proceedings of the Society of Antiquaries of Scotland" 121, 335-357.

Capwell T. 2002. A Depiction of an Italian Arming Doublet, c. 1435-45. "Waffen- und Kostümkunde. Zeitschrift für Waffen- und Kleidungsgeschichte“ 2002(2), 177-195.

Cymbalak T., Svatošová S. 2015. Nestelhülsen - dutá oděvní nákončí ve středověké a novověké Praze. "Staletá Praha" 31(2), 2-15.

Egan G., Hayward M. 2012. Points. In: G. Owen-Crocker, E. Coatsworth, M. Hayward (eds.), Encyclopedia of Dress and Textiles in the British Isles c. 450-1450. Leiden, Boston, 421-422.

Egan G., Pritchard F. 2002. Medieval Finds from Excavations in London 3: Dress Accessories c. 1150-c. 1450. London.

Frieder Waugh C. 1999. 'Well-Cut Through the Body': Fitted Clothing in Twelfth-Century Europe. "Dress" 26(1), 3-16.

Januszkiewicz B. 1995. Klejnoty i stroje książat Pomorza Zachodniego XVI-XVII wieku w zbiorach Muzeum Narodowego w Szczecinie. Warszawa.

Krabath S. 2001. Die hoch- und spätmittelalterlichen Buntmetallfunde nördlich der Alpen: eine archäologisch-kunsthistorische Untersuchung zu ihrer Herstellungstechnik, funktionalen und zeitlichen Bestimmung. Rahden.

Krasa J. 1971. Rukopisy Václava IV. Praha.

Maik J. 2004. Średniowieczne jedwabie z wykopalisk w Elblagu. In: R. Czaja, G. Nawrolska, M. Rębkowski, J. Tandecki (eds.), Archaeologia et historia urbana. Elbląg, 509-516.

Newton S. M. 1980. Fashion in the Age of the Black Prince: A Study of the Years 1340-1365. Suffolk. 
Nutz B. 2014. Drgens sn wir vs nvt schame. No Shame in Braiding 15th Century Fingerloop Braids from Lengberg Castle. "Estonian Journal of Archaeology" 18(2), 116-134.

Picken M. B. 1957. The Fashion Dictionary. New York.

Ryder L. M., Gabra-Sanders T. 1992. Textiles from Fast Castle, Berwickshire, Scotland, "Textile History" 23(1), 5-22.

Turska K. 1987. Ubiór dworski w Polsce w dobie pierwszych Jagiellonów. Wrocław, Warszawa, Kraków, Gdańsk, Łódź. 